\title{
Molecular Correlates of Laminar Differences in the Macaque Dorsal Lateral Geniculate Nucleus
}

\author{
Karl D. Murray, ${ }^{1}$ Carol M. Rubin, ${ }^{2}$ Edward G. Jones, ${ }^{1}$ and Leo M. Chalupa ${ }^{2,3}$ \\ ${ }^{1}$ Center for Neuroscience and Department of Psychiatry and Behavioral Sciences and 2Department of Neurobiology, Physiology, and Behavior, College of \\ Biological Sciences, University of California, Davis, Davis, California 95616, and ${ }^{3}$ Department of Ophthalmology and Vision Science, School of Medicine, \\ University of California, Davis, Davis, California 95817
}

In anthropoid primates, cells in the magnocellular and parvocellular layers of the dorsal lateral geniculate nucleus (dLGN) are distinguished by unique retinal inputs, receptive field properties, and laminar terminations of their axons in visual cortex. To identify genes underlying these phenotypic differences, we screened RNA from magnocellular and parvocellular layers of adult macaque dLGN for layer-specific differences in gene expression. Real-time quantitative reverse transcription-PCR and in situ hybridization were used to confirm gene expression in adult and fetal macaque. Cellular localization of gene expression revealed 11 new layer-specific markers, of which 10 were enriched in magnocellular layers (BRD4, CAV1, EEF1A2, FAM108A1, IN, , KCNA1, NEFH, NEFL, PPP2R2C, and SFRP2) and one was enriched in parvocellular and koniocellular layers (TCF7L2). These markers relate to functions involved in development, transcription, and cell signaling, with Wnt/ $\beta$-catenin and neurofilament pathways figuring prominently. A subset of markers was differentially expressed in the fetal dLGN during a developmental epoch critical for magnocellular and parvocellular pathway formation. These results provide new evidence for the molecular differentiation of magnocellular and parvocellular streams through the primate dLGN.

Key words: axon targeting; cell signaling; cytoarchitecture; plasticity; transcriptome; vision

\section{Introduction}

In the primate visual system, information is conveyed to the cerebral cortex via the dorsal lateral geniculate nucleus (dLGN) of the thalamus along parallel pathways comprised of neurons with distinct morphologies, connections, and neurochemical and physiological characteristics (Jones, 2007). The dLGN of Old World monkeys, apes, and humans is comprised of six distinct cellular layers recognizable on the basis of neuronal size and connections. The magnocellular layers, 1 and 2, which receive afferents from contralateral and ipsilateral retinas, respectively, are innervated by axons of parasol retinal ganglion cells and project to layers $4 \mathrm{C} \alpha$ and 6 of primary visual cortex. The parvocellular layers, 3-6, which receive afferents from contralateral (layers 4 and 6) and ipsilateral (layers 3 and 5) retinas, are innervated by midget ganglion cells, and project to layers $4 \mathrm{~A}$ and $4 \mathrm{C} \beta$ of primary visual cortex. A third set of cells, comprised of konicellular neurons localized in the $S$ layers and interlaminar plexuses, receives input from other retinal ganglion cells and project to superficial layers of striate cortex as well as to extrastriate areas

\footnotetext{
Received Aug. 8, 2008; accepted Sept. 18, 2008.

This work was supported by Research to Prevent Blindness; National Institutes of Health Grants EY003991 (L.M.C.), EY016182 (L.M.C.), P30 EY12576 (L.M.C.), NS21377 (E.G.J.), and NS39094 (E.G.J.); and the W. M. Keck Program in Cellular and Molecular Neuroscience Imaging. K.D.M. is the recipient of a Young Investigator Award from the National Alliance for Research in Schizophrenia and Depression and the Sunshine from Darkness Gala. We thank Lien Le and Phong Nguyen for expert technical assistance.

Correspondence should be addressed to Leo M. Chalupa, Department of Neurobiology, Physiology, and Behavior, 196 Briggs Hall, University of California, Davis, Davis, CA 95616. E-mail: Imchalupa@ucdavis.edu.

D0I:10.1523/JNEUROSCI.3800-08.2008

Copyright $\odot 2008$ Society for Neuroscience $\quad$ 0270-6474/08/2812010-13\$15.00/0
}

(Sincich et al., 2004; Sincich and Horton, 2005). An extensive literature has documented the physiological properties that differentiate magnocellular and parvocellular neurons of the macaque dorsal lateral geniculate nucleus, and this has led to the notion of parallel streams of visual function (for review, see Kaplan, 2004). In comparison, much less is known about the konicellular pathway (Hendry and Reid, 2000; Callaway, 2005).

Although considerable progress has been made in our understanding of underlying anatomical circuitry and functional properties that distinguish magnocellular from parvocellular layers of the macaque monkey dLGN, our knowledge of the molecular markers expressed by neurons in these layers is still rudimentary. Such information would be valuable for several reasons. It could provide a means by which homologies between magnocellular and parvocellular geniculate cells could be established among different species. Molecular markers differentiating neurons in the major layers of the monkey dLGN could also provide a means for monitoring visual system development and plasticity. Moreover, because magnocellular and parvocellular directed axons are segregated into their distinct cellular regions from the earliest period of development (Meissirel et al., 1997), such information could also prove relevant for unraveling the molecular cues that lead to the formation of these functional streams.

To probe the molecular basis of magnocellular and parvocellular pathways, in the present study we used a genome-wide transcriptional analysis of dLGN layers followed by confirmation of expression by reverse transcription (RT)-PCR and cellular mapping by in situ hybridization. We report identification of 11 new 
layer-specific dLGN markers in the adult macaque. Functional pathway analysis of these markers implicates $\mathrm{Wnt} / \beta$-catenin and neurofilament signaling as fundamentally involved in the remarkable morphological and functional specificity of dLGN lamination. We also provide evidence for the differential expression of a subset of these markers in the fetal monkey during a period when retinal axons have been reported to selectively innervate magnocellular and parvocellular segments of the geniculate anlage (Meissirel et al., 1997).

\section{Materials and Methods}

Animals. Brains from seven adult male monkeys (Macaca mulatta) and two fetal monkeys (Macaca fascicularis) at embryonic day 55 (E55) were used. Timed pregnancies were determined according to previously reported procedures (Warland et al., 2006). Gestational ages could be estimated to within $\pm 2 \mathrm{~d}$, with E1 corresponding to the first $24 \mathrm{~h}$ after mating. All procedures were performed using protocols approved by the Institutional Animal Care and Use Committee.

dLGN microdissection. Freshly removed adult brains were chilled and cut into 5-mm-thick coronal slices that were flash frozen between liquid nitrogen-cooled aluminum plates. Punches, $\sim 1 \mathrm{~mm}$ in diameter, were

Table 1. MAS5 quality control measures

\begin{tabular}{lcl}
\hline & Mean \pm SEM & ANOVA $p$ value \\
\hline Percentage present & $21 \pm 0.5$ & 0.6 \\
Noise (RawQ) & $3.9 \pm 0.3$ & 1.0 \\
Scaling factor & $5.7 \pm 0.3$ & 0.4 \\
GAPDH $\left(3^{\prime} / 5^{\prime}\right)$ & $10.8 \pm 0.8$ & 0.3 \\
\hline
\end{tabular}

taken from frozen slices containing the dLGN, using a sharpened, bluntended 15 gauge hypodermic needle. The slices from which the punches were taken were brought to $4^{\circ} \mathrm{C}$, immersed in $4 \%$ paraformaldehyde in $0.1 \mathrm{M}$ phosphate buffer, cryoprotected in $30 \%$ sucrose, refrozen, and later sectioned on a sliding microtome at $25 \mu \mathrm{m}$. Sections were stained by the Nissl method and used to localize punches to dLGN layers. Samples from the magnocellular layers were confined to those layers; samples from the parvocellular layers included cells of the interlaminar plexuses.

RNA isolation. Total RNA was isolated from the tissue-punches using Trizol reagent (Invitrogen), followed by affinity column purification (QIAGEN). RNA purity was determined by spectrophotometry and by using an Agilent 2100 Bioanalyzer (Agilent Technologies). To obtain enough probe for Affymetrix microarrays, $100 \mathrm{ng}$ of total RNA from each sample was subjected to two rounds of T7-based linear amplification (Van Gelder et al., 1990) using the MessageAmp II aRNA Amplification kit (Ambion). A separate set of punches from magnocellular and parvocellular layers was used to isolate total RNA as above, but without amplification. This RNA was used in RT-PCR experiments. Frozen samples of visual cortex and dorsal thalamus, including both magnocellular and parvocellular layers of dLGN, were used to isolate total RNA as above, without the amplification step. This RNA was later used for generating riboprobes for in situ hybridization histochemistry.

Microarray hybridization. RNA samples were processed for microarray analysis according to the sample labeling, hybridization, and scanning procedures recommended by Affymetrix. This entails the synthesis of double-stranded cDNA from the mRNA pool of isolated cellular total RNA, followed by in vitro transcription and labeling of cRNA. U133A Plus 2.0 human arrays were used for all samples. Three replicates of each set of layers from two monkeys for a total of 12 arrays were used.

Microarray analysis. Initial analysis was performed using Affymetrix

Table 2. RT-PCR primers

\begin{tabular}{|c|c|c|c|}
\hline Gene symbol & $\begin{array}{l}\text { Accession } \\
\text { no. }^{a}\end{array}$ & Sense primer ${ }^{b}$ & Antisense primer $^{b}$ \\
\hline TPBG & ВС037161 & ТСTCССАССTCСТCGGCATCC & TGGGCAGATGCTCGAAGGCGC \\
\hline TFE3 & BC026027 & GTCTCATGCGGCCGAACCAGC & TGGGCCCGCATTAGCTGCTGC \\
\hline TCF7L2 & BC032656 & CGCCTCGCTCCGAAAGTTTCC & CCGGCGTGAAGTGTTCATTGC \\
\hline SFRP2 & BC008666 & GCTGGCTGCTGCTGCTCTTCC & CAGAGCGAGTGGCATGGCTGG \\
\hline$P P P 2 R 2 C$ & ВC032954 & TCCATCCGCACCACTGCAACC & TGACGCTGTCGCTCCCGTTCC \\
\hline OPLAH & BC150206 & CGAGGGCCGCTTCCACTTTGC & GCTTGGGTGCCAATGTGCAGC \\
\hline ODZ3 & AK001336 & CGCCCATCTTCGGAGTCCAGC & TGCCGTTCTCCAGGGCCTTGC \\
\hline NEFM & NM_005382 & TCGAGCTTCAGCCGCGTCAGC & TCTCCTGGTCGTACGCGTCGC \\
\hline NEFL & NM_006158 & CTCGACCTCCTACAAGCGGCG & AGCACCAGCAGCTCGGCTTCC \\
\hline NEFH & NM_021076 & ATGATGAGCTTCGGCGGCG & ACCTTGTCGATGTACCCGGCG \\
\hline KCNA1 & BC101733 & AGAACGTGGACGAGGCTTCGG & CCCGGAACTTCTCCATGGCC \\
\hline$I N \alpha$ & BC003659 & GCTTCGGCTCGGAGCACTACC & CGATGAACACGGCGAAGCGG \\
\hline FAM108A1 & BC071644 & CTGCTGCCTCTTCTGCTGCCC & TGCCGTGCGAGAAGAGGACCG \\
\hline EEFTA2 & BC018855 & TCAACATCGTGGTCATCGGCC & CCATTCTTGGAGATGCCCGCC \\
\hline CAV1 & BC082246 & GCACAGCCCAGGGAAACCTCC & TCTCCTTGGTGTGCGCGTCG \\
\hline BRUNOL4 & BC045711 & CCTCAGTACCAACGGGCTCGG & TGGCTGTCCGCAGGCTTCACC \\
\hline BRD4 & BC091649 & GCATCGACTCCTCCGCAGACC & TTCACAGGCCGGCTGCTCTCC \\
\hline
\end{tabular}

${ }^{a}$ Public database source sequence accession numbers.

${ }^{b}$ Oligonucleotide primers are listed in 5' to $3^{\prime}$ orientation.

Table 3. Primary antibodies

\begin{tabular}{|c|c|c|c|c|c|c|c|}
\hline Antibody & Antibody type & Host & Source & Catalog no. & Dilution & Antigen & Reference(s) \\
\hline SMI-32 & Monoclonal & Mouse & Covance & SMI-32R & $1: 1000$ & $\begin{array}{l}\text { Nonphosphorylated neurofilament- } \mathrm{H} \text { and }-\mathrm{M} \\
\text { from dissected hypothalamus }\end{array}$ & $\begin{array}{l}\text { Sternberger et al., 1982; Sternberger and } \\
\text { Sternberger, } 1983\end{array}$ \\
\hline Cat-301 & Monoclonal & Mouse & $\begin{array}{l}\text { Millipore Bioscience Research } \\
\text { Reagents }\end{array}$ & MAB5284 & $1: 2000$ & $\begin{array}{l}\text { Chondroitin sulfate proteoglycan from dis- } \\
\text { sected, formaldehyde-fixed, spinal cord } \\
\text { gray matter }\end{array}$ & $\begin{array}{l}\text { McKay and Hockfield, 1982; Zaremba et al., } \\
1989\end{array}$ \\
\hline CAMK2A & Monoclonal & Mouse & $\begin{array}{l}\text { Millipore Bioscience Research } \\
\text { Reagents }\end{array}$ & $05-532$ & $1: 1000$ & Affinity-column-purified rat CAMK2A & Erondu and Kennedy, 1985 \\
\hline TCF7L2 & Polyclonal & Rabbit & Zymed & $34-3800$ & $1: 200$ & $\begin{array}{l}\text { Human TCF7L2 N-terminal (amino acids } \\
\text { 31-331) synthetic peptide }\end{array}$ & Barker et al., 1999 \\
\hline
\end{tabular}


Microarray Suite 5.0 (MAS5) software to determine the quality of the microarray data. Percentage present calls, background noise $(Q)$, the scaling factor, and the ratio of $3^{\prime} / 5^{\prime}$ hybridization for glyceraldehyde 3-phosphate dehydrogenase (GAPDH) were used to assess quality of hybridization (Table 1). Significant variability across samples was determined by ANOVA (Table 1). For subsequent analyses, Affymetrix $\mathrm{Cel}$ files were preprocessed by robust multichip analysis using GeneSpring GX (version 7.3.1) software (Agilent Technologies) followed by "per gene" and "per chip" median polishing. Parvocellular and magnocellular enriched genes were identified using fold expression difference and $p$ value cutoffs.

Ingenuity pathways analysis. A data set containing expression values and gene identifiers (microarray data) or gene identifiers alone (confirmed cell-specific dLGN markers) was uploaded into the on-line ingenuity pathways analysis (IPA) software application. Each gene identifier was mapped to its corresponding gene object in the Ingenuity Pathways Knowledge Base. For microarray data, a fold difference of 1.5 and a value of $p<0.05$ were used to identify genes whose expression was significantly differentially regulated. These genes, called focus genes, were overlaid onto a global molecular network developed from information contained in the Ingenuity Pathways Knowledge Base. Networks of these focus genes were then algorithmically generated based on their connectivity. A second data set containing genes with known cellular expression patterns was also interrogated using IPA software.

Analysis of function identified biological processes and/or diseases that were significantly overrepresented by genes associated with the data set. Fisher's exact test was used to calculate a $p$ value determining the probability that each biological function and/or disease assigned to that data set was attributable to chance alone.

Real-time PCR. Real-time PCR was performed using an iCycler (Bio-Rad) to measure incorporation of the fluorescent dye SYBR Green I. For each reaction, a master mix of the following was made: $1 \times$ PCR buffer (QIAGEN), $400 \mathrm{~mm}$ dNTP, $0.5 \mathrm{~mm}$ forward and reverse primers (Operon), $0.01 \times$ SYBR Green I (Invitrogen), $1.5 \mathrm{~mm} \mathrm{MgCl}_{2}, 10$ nм FITC (Bio$\mathrm{Rad}$ ), and $1 \mathrm{U}$ of TaqDNA polymerase (QIAGEN). All PCRs were optimal for the following cycle conditions, $94^{\circ} \mathrm{C}(15 \mathrm{~s}), 60^{\circ} \mathrm{C}(30 \mathrm{~s})$, and $72^{\circ} \mathrm{C}(30 \mathrm{~s})$, and were run for 40 cycles. After the PCR, a melting-curve analysis was performed to confirm the specificity of the PCR. In addition, samples of the PCRs were subjected to electrophoresis to verify product size and specificity. The relative quantification of RNA targets was performed as follows: The threshold cycle $(\mathrm{Ct})$ at which a gene of interest first rose above background was determined and subtracted from that of the housekeeping gene, $\beta$-actin, the PCR for which was performed in a separate reaction tube. This was termed $\Delta \mathrm{Ct}$. The $\Delta \mathrm{Ct}$ for each reaction was then subtracted from the control tissue sample and this $\Delta \Delta \mathrm{Ct}$ value was plotted as $2^{-\Delta \Delta \mathrm{Ct}}$. Therefore, all values are for RNA expression normalized to $\beta$-actin mRNA and a control tissue. Oligonucleotide primers used for PCR are listed in Table 2.

Riboprobes. Oligonucleotide primers flanking 300-400 bp of the coding region for each gene interrogated were designed using Vector NTi

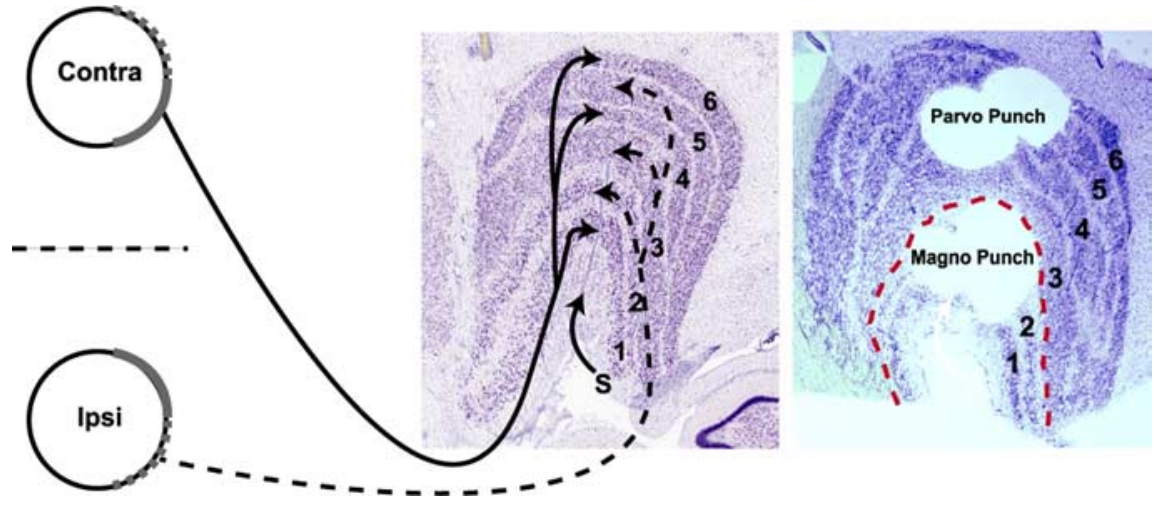

Figure 1. A schematic diagram identifying the target dLGN layers harvested for microarray analysis (left). Contralateral and ipsilateral retinal ganglion cell axons originate from nasal and temporal retinal ganglion cells, respectively, and terminate in layers 2) and inner (3-6) layers form the magnocellular and parvocellular visual streams, respectively. The Slayers are indicated (arrow). Magnocellular and parvocellular layers after microdissection with tissue punches are shown by post hoc Nissl staining (right).

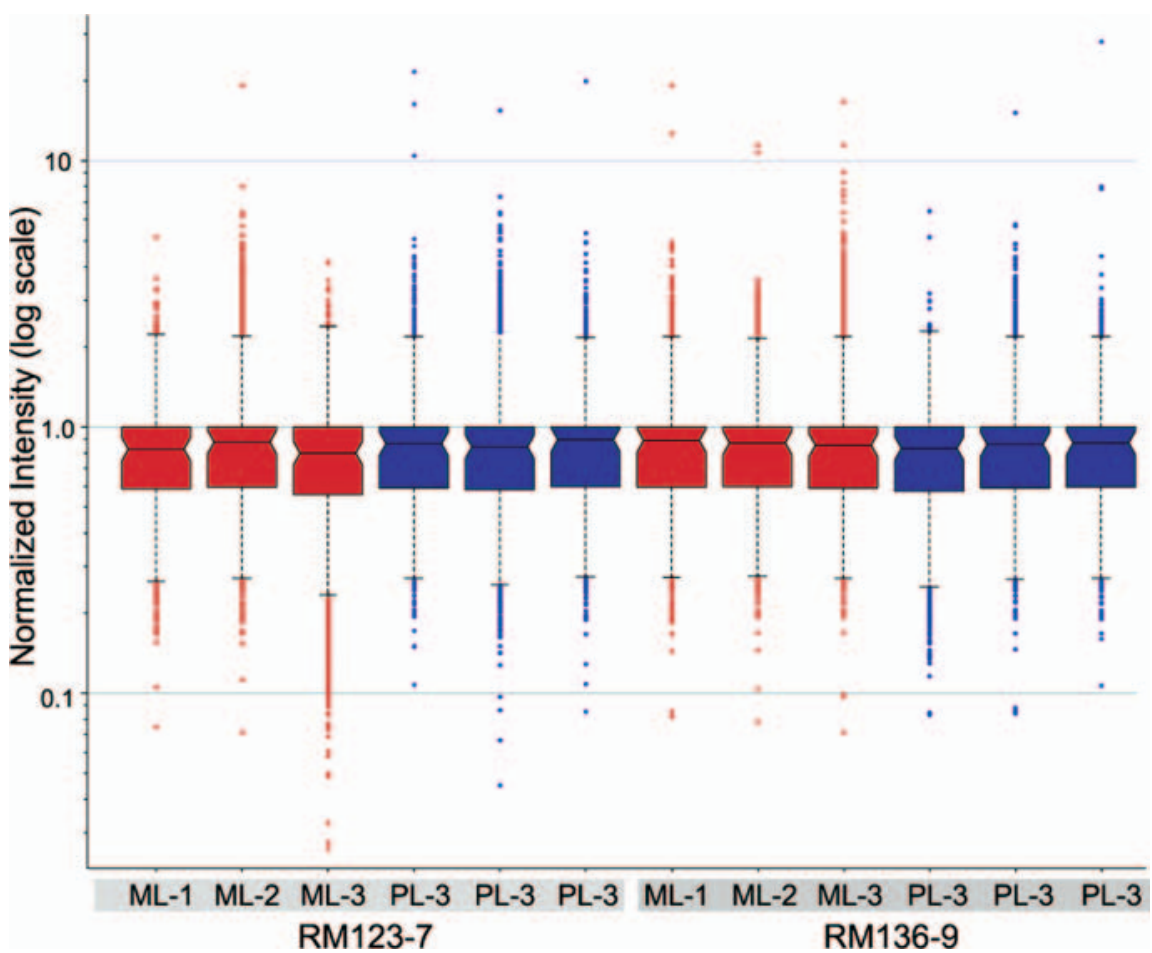

Figure 2. Distribution of normalized microarray data. Box plots representing robust multichip analysis and median polished gene expression data show a lack of variability in distribution between individual GeneChips. Samples from magnocellular (ML) (red) or parvocellular (PL) (blue) layers showed similar distributions in biological replicates (monkey RM123-7 versus monkey RM136-9) and between technical replicates within the same monkey.

Advance software (version 10.3) (Invitrogen). Each primer pair and the associated GenBank accession number are listed in Table 2. Target genes were amplified by PCR using cDNA obtained from combined visual cortex and dorsal thalamic total RNA and subcloned into PCRII-Topo (Invitrogen). Antisense cRNA probes were generated from linearized plasmids using either T7 or SP6 RNA polymerase in the presence of $\left[{ }^{35}\right.$ S $]$ UTP.

In situ hybridization histochemistry. Tissue from adult monkey brain, used for in situ hybridization, was generated from 5-mm-thick coronal brain slices, obtained in the same manner as those used for dLGN punches, but raised to $4^{\circ} \mathrm{C}$ and fixed in fresh $4 \%$ paraformaldehyde for $24 \mathrm{~h}$. The fixed slices were cryoprotected in $30 \%$ sucrose in $0.1 \mathrm{M}$ phosphate buffer at $4^{\circ} \mathrm{C}$ and frozen sections, $25 \mu \mathrm{m}$ thick, were cut on a sliding microtome and postfixed in fresh $4 \%$ paraformaldehyde at $4^{\circ} \mathrm{C}$ for at 
A

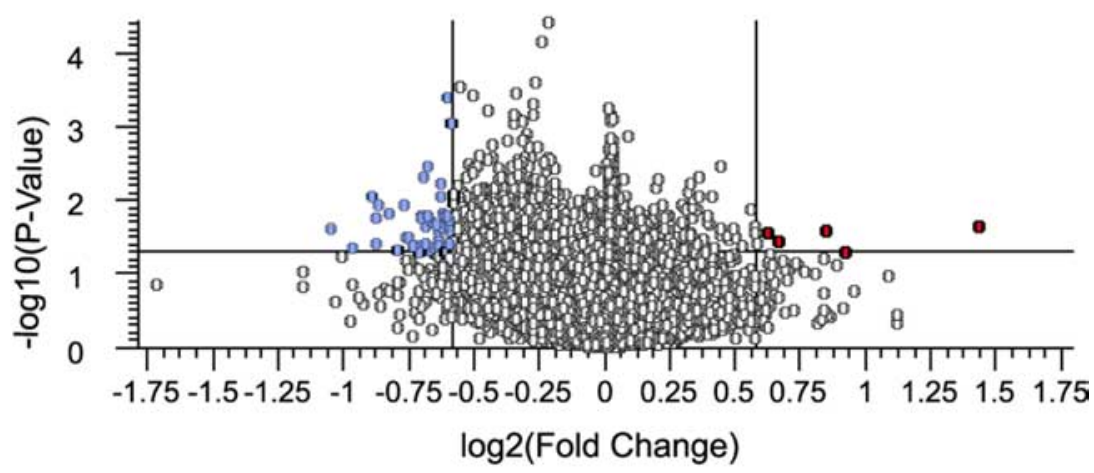

B

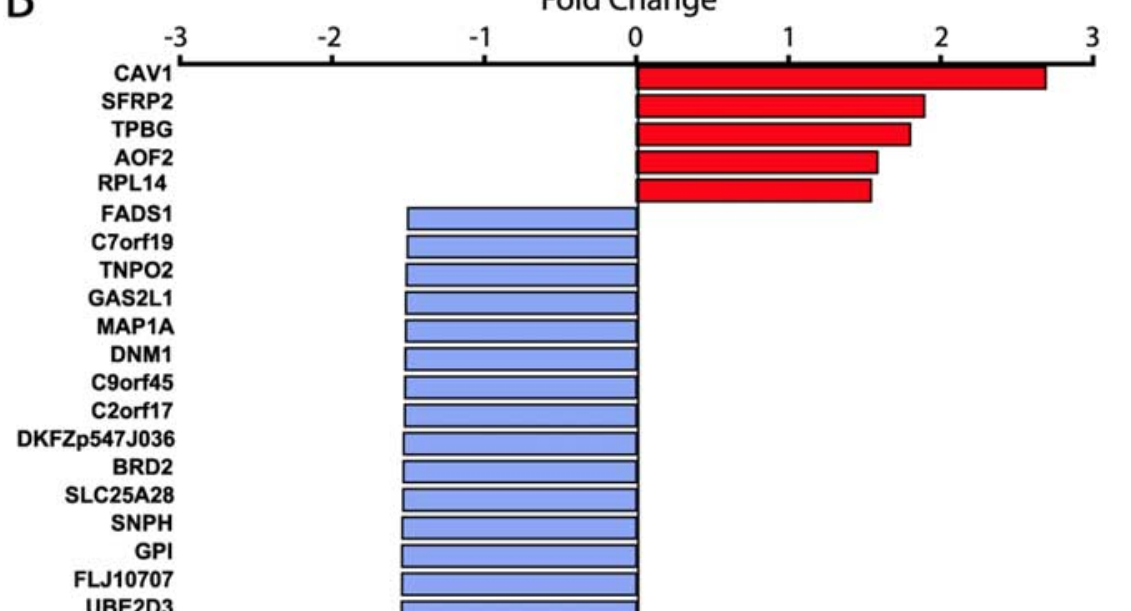

Figure 3. Genes differentially expressed in dLGN layers identified by microarray analysis. $\boldsymbol{A}$, Volcano plot of robust multichip analysis and median polished Affymetrix GeneChip data. Fold expression levels between magnocellular and parvocellular layers are plotted on the $x$-axis ( $\log _{2}$ transformed) and $t$ statistic $p$ values are plotted on the $y$-axis $\left(-\log _{10}\right.$ transformed). Genes that displayed at least a 1.5-fold difference and a value of $p<0.05$ are indicated in the top left and right quadrants of the plot. $\boldsymbol{B}$, Genes identified in the volcano plot as having matched the cutoff criteria are hierarchically listed here by fold increase in parvocellular layers (red) compared with magnocellular layers (blue). least $7 \mathrm{~d}$. Before hybridization, sections were rinsed in saline, sodium citrate (SSC) $(1 \times$ SSC consists of $0.88 \% \mathrm{NaCl}$ and $0.44 \%$ $\mathrm{Na}_{3} \mathrm{C}_{6} \mathrm{H}_{5} \mathrm{O}_{3} \cdot 2 \mathrm{H}_{2} \mathrm{O}$ ) and treated with proteinase $\mathrm{K}$ followed by acetic anhydride in $0.1 \mathrm{M}$ triethanolamine. After two brief rinses in SSC, sections were incubated in hybridization buffer containing $50 \%$ formamide, $10 \%$ dextran sulfate, $0.7 \%$ polyvinyl pyrolidone, $0.7 \%$ bovine serum albumin, $0.7 \%$ Ficoll, $0.15 \mathrm{mg} / \mathrm{ml}$ yeast tRNA, $0.33 \mathrm{mg} / \mathrm{ml}$ denatured herring sperm DNA, and $20 \mu \mathrm{M}$ dithiothreitol, and then transferred to fresh hybridization buffer containing an additional $20 \mu \mathrm{M}$ dithiothreitol and the ${ }^{35} \mathrm{~S}$ labeled antisense riboprobe at $10 \times 10^{6} \mathrm{cpm} / \mathrm{ml}$ $\left(24 \mathrm{~h} ; 60^{\circ} \mathrm{C}\right)$. After hybridization, sections were rinsed in SSC, treated with ribonuclease A for $30 \mathrm{~min}$ at $45^{\circ} \mathrm{C}$, and washed through a series of descending concentrations of SSC. Sections were mounted onto Vectabond (Vector Laboratories)-treated slides and exposed to Kodak autoradiographic film (GE Healthcare) For each gene examined, sense strand-specific cRNA probes were generated and hybridized to a series of sections as controls.

Tissue from embryonic monkey brain, processed for in situ hybridization, was obtained from fresh brain that had been removed and immediately immersed in fresh, ice-cold, $4 \%$ paraformaldehyde for $4 \mathrm{~d}$. After fixation, brains were rinsed in $0.1 \mathrm{M}$ phosphate buffered saline and cryoprotected in 30\% sucrose in PBS at $4^{\circ} \mathrm{C}$. Before sectioning, brains were embedded in OCT (Ted Pella) and frozen. Brain sections were cut at $12 \mu \mathrm{m}$, on a Leica cryostat and mounted onto poly-L-lysine-coated glass slides (Sigma-Aldrich), and then stored at $-80^{\circ} \mathrm{C}$ in desiccated containers until additional processing. On the day of in situ hybridization, slidemounted sections were warmed to room temperature and processed using solutions and incubation times detailed above for freefloating adult tissue sections.

Digital images of film autoradiographs were acquired using a Power Phase FX digital camera (Phase One). Images $(10,500 \times 12,600)$ were saved as TIFF files and optimized for contrast and size only in Adobe Photoshop (version 6.0; Adobe Systems). Subsequently, images were composed into figures using Adobe Illustrator CS2 (Adobe Systems).

Quantification of in situ hybridization histochemistry. Quantitative measurements of film autoradiographs were made by densitometric analysis using the MCID imaging system (Imaging Research). Optical density readings from each dLGN layer were normalized to ${ }^{14} \mathrm{C}$ reference standards exposed on the same film. Mean values for each dLGN layer were obtained from two to five sections from three to five different animals. Statistical significance, $p<0.05$, was determined by ANOVA with repeated measures and post hoc Student's $t$ test using Excel software (Microsoft).

Immunohistochemistry. Sections, $25 \mu \mathrm{m}$ thick, were obtained from coronal brain slices as for in situ hybridization, but were placed directly into $0.1 \mathrm{M}$ phosphate buffer, $\mathrm{pH} 7.4$, and maintained at $4^{\circ} \mathrm{C}$ for no longer than $7 \mathrm{~d}$. Sec- 
tions were immersed for $1 \mathrm{~h}$ in blocking buffer $(0.1 \mathrm{M}$ phosphate buffer, pH 7.4, $0.25 \%$ Triton X-100, 10\% normal horse serum) at room temperature, and then transferred to antibody incubation buffer $(0.1 \mathrm{M}$ phosphate buffer, $\mathrm{pH} 7.4,0.25 \%$ Triton $\mathrm{X}-100,5 \%$ normal horse serum) containing one or two primary antibody(ies) at empirically derived dilutions (Table 3 ) and incubated overnight at $4^{\circ} \mathrm{C}$. The following day, sections were rinsed in $0.1 \mathrm{M}$ phosphate buffer and transferred to antibody incubation buffer containing either biotin (Vector Laboratories)-, Alexa Fluor 488 (Invitrogen)-, or Alexa Fluor 568 (Invitrogen)conjugated secondary antibody(ies). After $1 \mathrm{~h}$ incubation at room temperature, sections bound with biotinylated antibody were rinsed in $0.1 \mathrm{M}$ phosphate buffer, incubated in ABC (avidin-biotin-peroxidase complex) (Vector Laboratories) for $1 \mathrm{~h}$ at room temperature, and then rinsed and reacted with $0.02 \%$ DAB $\left(3,3^{\prime}\right.$-diaminobenzidine $4 \mathrm{HCl}$ ) (SigmaAldrich) and $0.03 \%$ hydrogen peroxidase in $0.1 \mathrm{~m}$ phosphate buffer, $\mathrm{pH}$ 7.4. After brief washes in $0.1 \mathrm{~m}$ phosphate buffer, sections were mounted onto glass slides, air dried, dehydrated in ascending alcohols, cleared with xylene, and finally coverslipped with DPX mounting medium (BDH). Sections incubated in fluorescently conjugated secondary antibody(ies) were washed in $0.1 \mathrm{M}$ phosphate buffer, mounted onto glass slides, and coverslipped with Prolong Antifade (Invitrogen) supplemented with Hoechst 33342 (Invitrogen). Immunoperoxidase staining of sections through the dLGN was performed using monoclonal antibodies SMI-32 and Cat-301 and a polyclonal antibody raised against transcription factor 7-like-2 (TCF7L2) (Table 3). Selected sections through the dLGN were used for double immunofluorescent staining with antibodies against TCF7L2 and the $\alpha$ subunit of type II calcium/calmodulin-dependent protein kinase (CAMK2A) (Table 3).

Digital images of immunoperoxidase-stained sections were acquired either by scanning slides at high resolution $(0.5 \mu \mathrm{m} /$ pixel $)$ using a Aperio T3 ScanScope (Aperio) or by using a Nikon Eclipse 1000 microscope (Nikon), equipped with a Quantix CCD digital camera (Photometrics). Acquired images were saved as TIFF files. Images of fluorescently labeled sections were obtained with a Zeiss LSM 510 META laser-scanning confocal microscope (Carl Zeiss Microimaging) using a Zeiss Plan-Neofluar $25 \times / 0.8$ Corr differential interference contrast objective with oil immersion. Sections were imaged at optical resolutions of $0.31 \mu \mathrm{m}$ (Alexa 488 channel) and $0.35 \mu \mathrm{m}$ (Alexa 568 channel) in the $x$-and $y$-axes. Stacks of $0.7 \mu \mathrm{m}$ optical slices ( $z$-axis optical resolution, $\sim 2 \mu \mathrm{m}$ ) were collapsed and saved as single TIFF image files. All digital images obtained were exported into Adobe Photoshop CS2 (Adobe Systems) where they were cropped and adjusted for brightness and contrast only. Final editing was performed using Adobe Illustrator CS2 (Adobe Systems).

\section{Results}

Molecular differentiation of magnocellular and parvocellular layers of the adult monkey dLGN

RNA isolated from punches confined to either magnocellular or parvocellular (with koniocellular) layers of monkey dLGN (Fig. 1) and hybridized to Affymetrix human microarrays identified a set of differentially expressed genes. The characteristics of hybridization were similar to those previously observed for monkey RNA on human Affymetrix microarrays (Murray et al., 2007). Qualitative control measures detected no significant differences across individual microarrays as judged by percentage present calls, the scaling factor, or level of noise (RawQ) determined using Affymetrix MAS5 software (Table 1). The distribution of normalized expression data was not different across GeneChips (Fig. 2).

Genes that were overrepresented in magnocellular or parvocellular (with koniocellular) layers by a fold difference of at least 1.5 and a value of $p<0.05$ were identified by volcano plot analysis (Fig. 3; supplemental Table 1, available at www.jneurosci.org as supplemental material). A total of 50 genes met these criteria and the overwhelming majority was greater in magnocellular than in parvocellular layers (Fig. 3).

Analysis of differentially expressed genes using IPA software

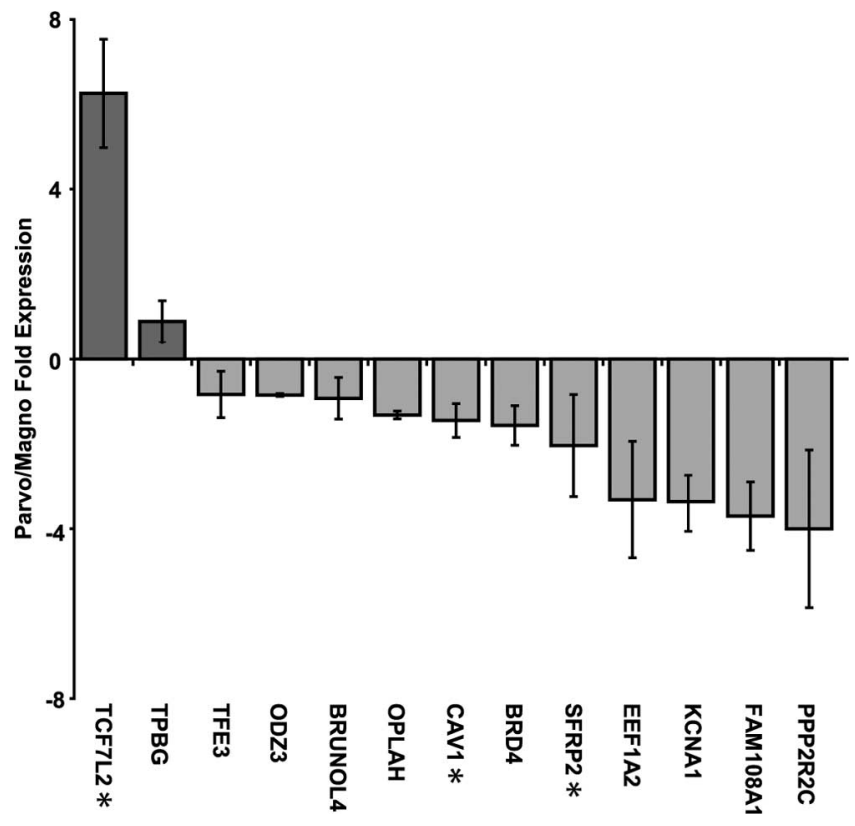

Figure 4. RT-PCR confirmation of microarray measures. Twelve of the top genes identified by microarray were analyzed independently by RT-PCR. Each gene was measured in triplicate and plotted as fold increase in parvocellular (dark gray) expression levels over magnocellular (light gray) expression. Genes with fold differences opposite those observed by microarray are indicated $\left(^{*}\right)$. The bars indicate mean values \pm SEM.

revealed an overabundance of sets of genes in $>70$ categories related to molecular and cellular functions, physiological system development and function, or diseases and disorders (supplemental Table 2, available at www.jneurosci.org as supplemental material). Among the top categories identified were those involving functions related to development, gene expression, cell growth, and tissue morphology. In addition, analysis of genes for potential interactions identified several putative protein networks involving functions related to cellular signaling, development, and motility (supplemental Table 3 and supplemental Fig. 1 , available at www.jneurosci.org as supplemental material). Several canonical pathways were overrepresented. Among these, the Wnt $/ \beta$-catenin, Toll-like receptor signaling, calcium signaling, and cAMP signaling pathways were the most statistically significant.

\section{RT-PCR}

To confirm the microarray results, we performed RT-PCR analysis on 13 of the top differentially expressed genes and ranked them according to fold increase (Fig. 4). Of these, 10 genes (BRD4, BRUNOL4, EEF1A2, FAM108A1, KCNA1, OD23, OPLAH, PPP2R2C, TEF3, and TPBG) showed a fold increase in the same direction observed by microarray analysis. Three genes (TCF7L2, SFRP2, and CAV1) showed a fold increase in the direction opposite to that observed by microarray. Eleven genes (BRD4, BRUNOL4, CAV1, EEF1A2, FAM108A1, KCNA1, ODZ3, OPLAH, PPP2R2C, SFRP2, and TFE3) were identified as enriched in magnocellular layers (Fig. 4, light gray bars) and two (TCF7L2 and TPBG) as enriched in parvocellular layers (Fig. 4, dark gray bars) according to RT-PCR.

\section{Cellular confirmation of differential gene expression}

To determine the cellular gene expression patterns in dLGN, we performed in situ hybridization on all 13 differentially expressed 

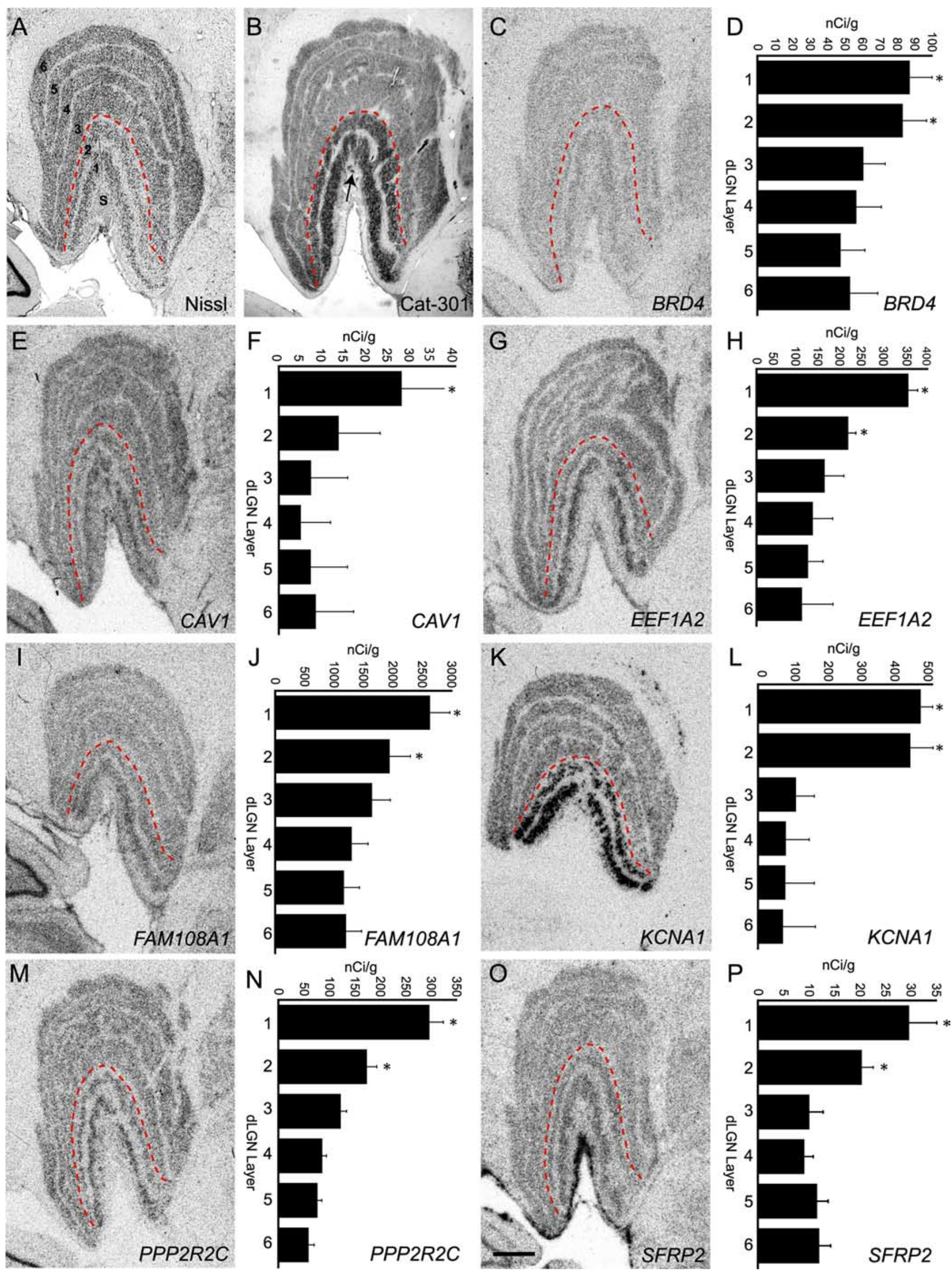
genes identified through RT-PCR. Differential patterns of gene expression are described in detail below.

\section{Magnocellular enriched gene expression}

The genes, BRD4, CAV1, EEF1A2, FAM108A1, KCNA1, $P P P 2 R 2 C$, and SFRP2, identified as magnocellular enriched by RT-PCR were confirmed by in situ hybridization (Fig. 5). All seven genes displayed a similar pattern of expression throughout the dLGN, although their level of expression varied dramatically. Overall levels of hybridization were much lower for $C A V 1$, SFRP2, and BRD4 compared with EEF1A2, FAM108A1, KCNA1, and $P P P 2 R 2 C$ (compare scales in Fig. 5).

Both CAV1 and SFRP displayed hybridization patterns consistent with RT-PCR, although not microarray. Autoradiograms revealed positive hybridization over all principal layers of the dLGN, but stronger hybridization was observed over the magnocellular layers (Fig. 5). Only background levels of hybridization were observed over the $S$ layers or over the interlaminar zones for either CAV1 or SFRP2. Densitometric analysis of hybridization levels confirmed $C A V 1$ and SFRP2 expression levels were elevated in magnocellular layers of the dLGN (Fig. 5).

Five genes, BRD4, EEF1A2, FAM108A1, KCNA1, and $P P P 2 R 2 C$, displayed patterns of hybridization consistent with both microarray and RT-PCR results. Expression of BRD4 was rather low, but EEF1A2, KCNA1, FAM108A1, and PPP2R2C were expressed at high levels within the magnocellular layers of the dLGN (Fig. 5). Autoradiographs for all five genes revealed hybridization signal overlying the principal layers of the dLGN, but only low or no signal over the S layers or interlaminar zones (Fig. $5)$. Densitometric analysis confirmed that expression of these genes was greater in magnocellular layers compared with parvocellular layers (Fig. 5). Statistically higher expression of $B R D 4$, EEF1A2, FAM108A1, KCNA1, PPP2R2C, and SFRP2 was observed in magnocellular layers 1 and 2 compared with parvocellular layers and of $C A V 1$ in magnocellular layer 1 compared with parvocellular layers, according to ANOVA and post hoc Student's $t$ test (Fig. 5).

\section{Parvocellular (and koniocellular) enriched TCF7L2 expression}

A single gene, TCF7L2, was found to be enriched in parvocellular/ koniocellular relative to magnocellular layers of the dLGN. Expression of TCF7L2 mRNA was previously observed to be restricted to nuclei of the dorsal thalamus including the dLGN (Murray et al., 2007). Within the dLGN, TCF7L2 mRNA levels

\footnotetext{
$\leftarrow$

Figure 5. In situ hybridization confirmation of magnocellular enriched gene expression. $\boldsymbol{A}$, Coronal Nissl-stained section through monkey dLGN illustrating the cytoarchitecture, including the six principal cell layers and the $S$ layers $(S)$. The red dashed line indicates the separation between magnocellular (1 and 2) and parvocellular (3-6) layers. $\boldsymbol{B}$, Coronal section through monkey dLGN immunostained with monoclonal antibody Cat-301, which recognizes an epitope on the protein aggrecan and is known to be elevated in magnocellular dLGN layers (Hendry et al., 1984). Some staining in S layers is also present (arrow). C, $\boldsymbol{E}, \mathbf{G}, \mathbf{I}, \boldsymbol{K}, \boldsymbol{M}, \mathbf{0}$, Images of film autoradiograms illustrating hybridization of radioactive CRNA probes specific to the genes BRD4 (C), CAV1 (E), EEF1A2 (G), FAM108A1 (I), KCNA1 (K), PPP2R2C (M), and SFRP2 (0) on coronal sections of monkey dLGN. Consistent with RT-PCR results, each gene displayed elevated expression in one or both magnocellular layers. $\boldsymbol{D}, \boldsymbol{F}, \boldsymbol{H}, \boldsymbol{J}, \boldsymbol{L}, \boldsymbol{N}, \boldsymbol{P}$, Laminar differences in mRNA expression were quantified from film autoradiograms of sections processed for in situ hybridization for BRD4 (D), CAV1 $(\boldsymbol{F})$, EEF1A2 $(\boldsymbol{H})$, FAM108A1 (J), KCNA1 ( $)$, PPP2R2C (N), and SFRP2 $(\boldsymbol{P})$. Calibrated densitometric measures were obtained from the principal layers (1-6) of the dLGN. Measures are means \pm SEM. ${ }^{*} p<0.01(n=5)$, ANOVA, post hoc Student's t test. Scale bar: (in $\mathbf{0}) \boldsymbol{C}, \boldsymbol{E}, \boldsymbol{G}, \boldsymbol{I}, \boldsymbol{K}, \boldsymbol{M}, 1 \mathrm{~mm}$.
}
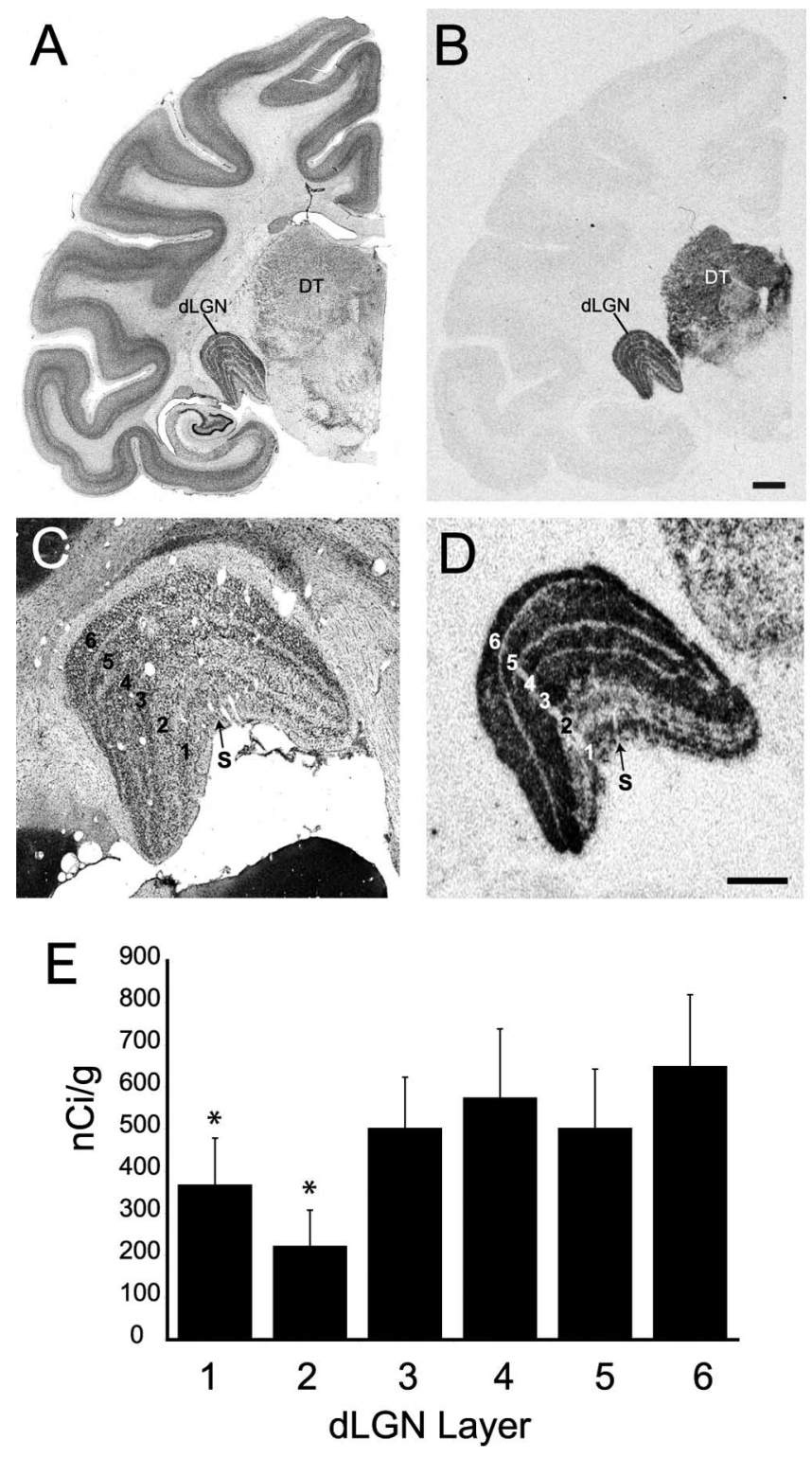

Figure 6. TCF7L2 mRNA expression is overrepresented in parvocellular layers of monkey dLGN. A, Bright-field image of a Nissl-stained coronal section of monkey brain at the level of mid-dLGN. B, Image from a film autoradiogram illustrating in situ hybridization for TCF7L2 mRNA in a coronal section adjacent to that in $A$. TCF7L2 mRNA is mostly restricted to dorsal thalamus (DT) and shows prominent expression in dLGN. C, Higher power image of Nisslstained dLGN showing the principal relay layers (1-6) and the S layers. $\boldsymbol{D}$, Higher power image of a section adjacent to that in C showing TCF7L2 in situ hybridization. TCF7L2 mRNA expression is greater in the parvocellular layers (3-6) compared with magnocellular layers (1, 2). Hybridization to TCF7L2 mRNA is also observed in the Slayers. $\boldsymbol{E}$, Calibrated densitometric measures of film autoradiographs illustrate the enrichment for $T C F 7 L 2$ hybridization in parvocellular layers compared with magnocellular layers. Measures are means \pm SEM. ${ }^{*} p<0.01(n=5)$, ANOVA, post hoc Student's $t$ test. Scale bars: (in $\boldsymbol{B}) \boldsymbol{A}, \boldsymbol{B}, 2 \mathrm{~mm}$; (in $\boldsymbol{D}) \boldsymbol{C}, \boldsymbol{D}, 1 \mathrm{~mm}$.

were appreciable in cells of all principal layers and in scattered cells throughout the S layers (Fig. 6). As predicted by RT-PCR analysis, mRNA expression was greater in parvocellular than in magnocellular layers. Densitometric analysis revealed that expression of TCF7L2 mRNA in magnocellular layers 1 and 2 was significantly lower than in parvocellular (with koniocellular) layers as determined by ANOVA and post hoc Student's $t$ test (Fig. 6). TCF7L2 expression was up to three times greater in the parvocellular compared with the magnocellular layers (Fig. 6 F). Differential expression between parvocellular and magnocellular layers 

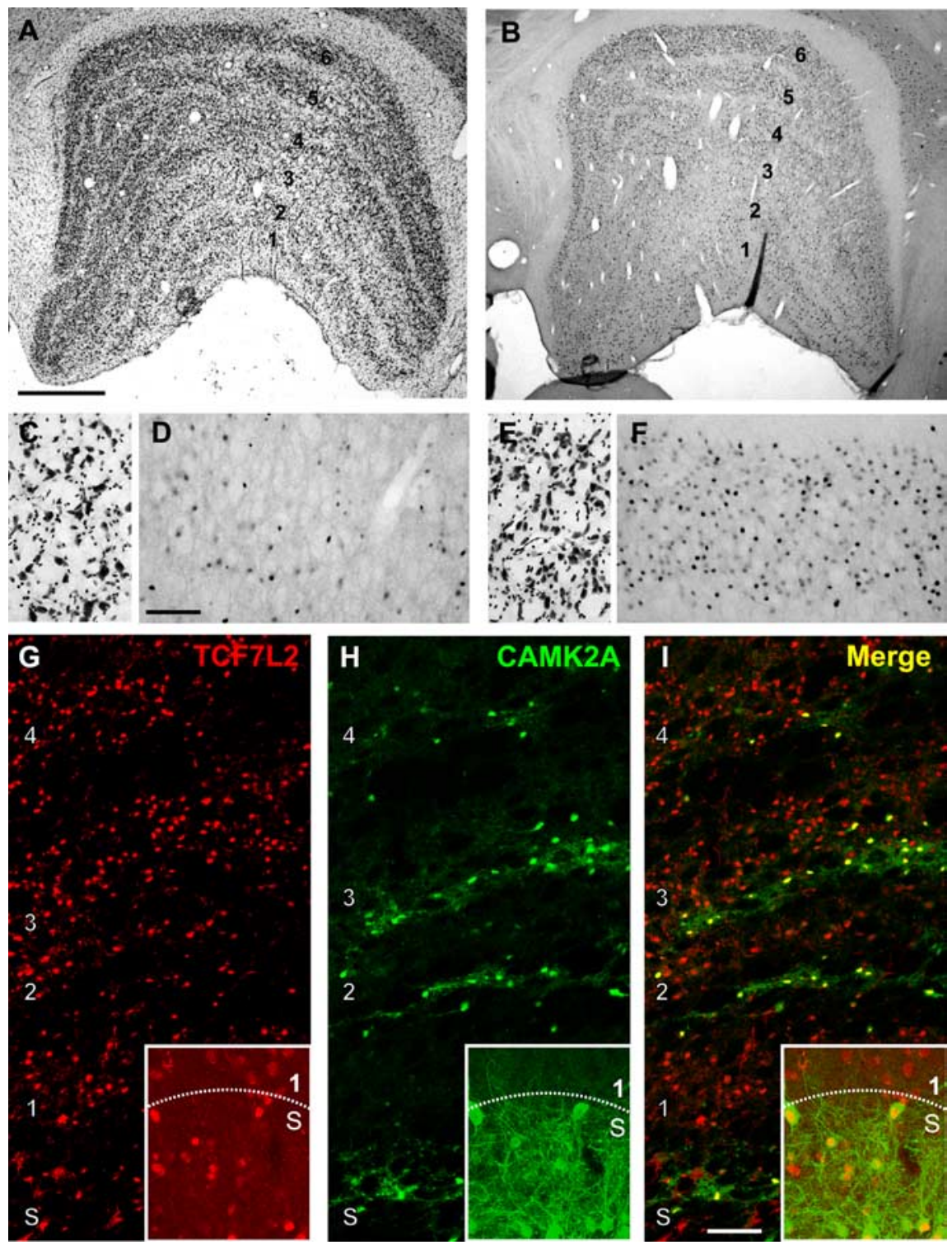

Figure 7. TCF7L2 protein is enriched in parvocellular, $S$, and intercalated layers of the monkey dLGN. $\boldsymbol{A}$, Nissl-stained coronal section of monkey dLGN illustrating the principal relay layers (1-6) and the intercalated layers that separate them. The Slayers are not readily visible in this section. $\boldsymbol{B}$, Immunohistochemical labeling of TCF7L2 protein in a coronal section of monkey dLGN adjacent to that in $\boldsymbol{A}$. $\boldsymbol{C}, \boldsymbol{E}$, Higher power images of Nissl-stained cells in layer $1(\boldsymbol{C})$ and $6(\boldsymbol{E})$ of dLGN. $\boldsymbol{D}, \boldsymbol{F}$, Higher power images from sections adjacent to those in $\boldsymbol{C}$ and $\boldsymbol{E}$ show immunoreactivity for TCF7L2 protein in layers $1(\boldsymbol{D})$ and $6(\boldsymbol{F})$ of dLGN. More immunoreactive cells are observed in layer 6 compared with layer 1. G-I, Double immunofluorescent labeling of TCF7L2 (red) and type II $\alpha$ calcium/calmodulin-dependent protein kinase (CAMK2A) (green) in dLGN. Merged images (I) show colocalization of TCF7L2 and CAMK2A in the intercalated layers of the dLGN and in the Slayers (insets). Scale bars: (in $A) A, B, 1 \mathrm{~mm}$; (in $\mathbf{D}) \mathbf{C}-\boldsymbol{F}, 250$ $\mu \mathrm{m}$; (in $I) \mathbf{G}-\mathbf{I}, 200 \mu \mathrm{m}$.

was observed along the rostrocaudal axis of the dLGN (data not shown).

The distribution of TCF7L2 protein was consistent with the pattern of mRNA expression. Immunocytochemical detection of TCF7L2 protein was restricted to nuclei of neurons. TCF7L2 protein expression was qualitatively higher in parvocellular than in magnocellular layers (Fig. 7). This appeared to be the effect of a larger number of cells expressing TCF7L2 (Fig. 7D,F). Expression of TCF7L2 protein was also observed in the $S$ layers and throughout the interlaminar zones in which koniocellular neurons are situated. Colocalization with immunostaining for CAMK2A, a marker of koniocellular neurons (Benson et al., 1991), confirmed that TCF7L2 was expressed in these neurons
(Fig. 7G-I). Levels of TCF7L2 were greater in koniocellular neurons of the $S$ layers than in neurons of the magnocellular layers (Fig. 7G-I).

In general, cellular patterns of differential gene expression in laminae of the adult dLGN can be summed up as follows: All but three genes displayed appreciable levels of autoradiographic signal in dLGN. Eight genes, BRD4, CAV1, EEF1A2, FAM108A1, KCNA1, PPP2R2C, SFRP2, and TCF7L2, displayed differential expression between magnocellular and parvocellular layers that was consistent with the RT-PCR results. The first seven were enriched in magnocellular layers, and the other, TCF7L2, was enriched in parvocellular and koniocellular layers. Two of the genes, TPBG and OPLAH, displayed no difference between magnocellular and parvocellular layers (data not shown).

Interrelatedness of confirmed cellspecific laminar dLGN markers

We investigated the potential interrelatedness of the layer-specific dLGN markers, identified at the cellular level, with previously characterized markers (Table 4). In a confirmed cell-specific marker list, we included all the known markers of dLGN except for the monoclonal antibodies SMI32 , which recognizes a posttranslational modification of neurofilament proteins (Sternberger et al., 1982; Sternberger and Sternberger, 1983), and Cat-301, which recognizes a surface proteoglycan ( $\mathrm{Za}$ remba et al., 1989). Immunoreactivity for these does not necessarily reflect the abundance of corresponding mRNA. In particular, Cat-301 immunoreactivity is enriched in, but not restricted to, magnocellular neurons (Hendry et al., 1984). Of 15 molecules interrogated, no less than 13 (ACAN, BRD4, CALB1, CAMK2A, CAV1, CRYAB, FSTL1 KCNA1, NEFM, PCP4, PPP2R2C, SFRP2, and TCF7L2) mapped to a single IPA network (Fig. 8). Functions associated with cellular growth and with development were significantly overrepresented in this network, consistent with IPA networks generated from the larger gene sets identified through microarray analysis (supplemental Table 4, available at www.jneurosci.org as supplemental material). Of the canonical pathways significantly overrepresented in the gene set identified through microarray, the $\mathrm{Wnt} / \beta$-catenin pathway was also overrepresented in the more focused confirmed cellular marker gene set (supplemental Fig. 2, available at www. jneurosci.org as supplemental material). Three genes identified in this study, PPP2R2C, TCF7L2, and SFRP2, were associated with the $\mathrm{Wnt} / \beta$-catenin canonical signaling pathway, contributing to its significant overrepresentation among the genes in Table 4.

Because immunolabeling with the monoclonal antibody SMI32, which recognizes nonphosphorylated forms of intermediate 
Table 4. Cellular markers of dLGN laminae

\begin{tabular}{|c|c|c|c|c|}
\hline Marker & Name/antigen & Layer specificity & Function & Reference \\
\hline BRD4 & Bromodomain containing 4 & Magno & Unknown & This study \\
\hline CALB1 & Calbindin 1 & Konio & Calcium ion binding & This study; Yan et al., 1996 \\
\hline CAMK2A & $\begin{array}{l}\alpha \text { Subunit of calcium/calmodulin-dependent } \\
\text { protein kinase type II }\end{array}$ & Konio & Protein serine/threonine kinase activity & Benson et al., 1991 \\
\hline CAV1 & Caveolin 1 & Magno & Integral membrane/structural molecule activity & This study \\
\hline CRYAB & $\alpha$ B-crystallin & Magno & Protein folding & Prasad et al., 2002 \\
\hline EEF1A2 & Eukaryotic translation elongation factor 1 a 2 & Magno & Translation initiation & This study \\
\hline FAM108A & $\begin{array}{l}\text { Family with sequence similarity } 108 \text {, member } \\
\text { A1 }\end{array}$ & Magno & Unknown & This study \\
\hline KCNA1 & $\begin{array}{l}\text { Potassium voltage-gated channel, shaker- } \\
\text { related subfamily, member } 1\end{array}$ & Magno & Delayed rectifier potassium channel activity & This study \\
\hline Monoclonal antibody Cat-301 & Aggrecan & Magno & Extracellular matrix organization and biogenesis & Hendry et al., 1984 \\
\hline Monoclonal antibody SMI-32 & $\begin{array}{l}\text { Nonphosphorylated forms of medium and } \\
\text { heavy neurofilament chains }\end{array}$ & Magno & & Gutierrez et al., 1995; Chaudhuri et al., 1996 \\
\hline NEFM & Neurofilament heavy chain & Magno & Structural constituent of cytoskeleton & Prasad et al., 2002 \\
\hline oCC1 & Follistatin-like-1 & Magno & Calcium ion binding/extracellular space & Tochitani et al., 2001 \\
\hline PCP4 & Purkinje cell protein 4 & Magno & Calcium ion binding & Kawasaki et al., 2004 \\
\hline PPP2R2C & Protein phosphatase $2 \mathrm{AB} 1 \gamma$ subunit & Magno & $\begin{array}{l}\text { Protein phosphatase activity, Wnt signaling } \\
\text { pathway }\end{array}$ & This study \\
\hline SFRP2 & Secreted frizzled-related protein 2 & Magno & Wnt signaling pathway, receptor & This study \\
\hline TCF7L2 & Transcription factor 7-like 2 & Parvo/Konio & Wnt signaling pathway, transcription factor & This study \\
\hline
\end{tabular}

neurofilament proteins, is specific to magnocellular layers of the dLGN, we asked whether there was a relationship between PPP2R2C, which encodes a subunit of phopsphatase 2A (Baek and Seeling, 2007) and NEFM, which encodes an intermediate neurofilament protein (Lee and Cleveland, 1996) (Fig. 8). Manual expansion of the nodes around these molecules revealed additional links with other known members of neurofilament complexes, IN $\alpha$, NEFL, and NEFH, as well as a connection to PPP2R2C protein (Fig. $8 A$ ). To determine whether these other molecules were also expressed in a layer-specific manner, we performed in situ hybridization with riboprobes specific for their mRNAs. Autoradiographs of in situ hybridization for NEFL, $N E F H$, and $I N \alpha$ revealed expression throughout the principal relay layers of the dLGN (Fig. 9). Little or no hybridization was observed over the $S$ layers or interlaminar zones. Similar to expression of PPP2R2C and NEFM, expression of NEFL, NEFH, and $I N \alpha$ was greater in the magnocellular layers.

\section{Expression in the fetal monkey}

To investigate whether lamina-specific gene expression observed in adult dLGN could play a role in establishing layers, we examined the expression of NEFL, IN $\alpha, N E F M$, and TCF7L2 at E55, a period during which formation of magnocellular and parvocellular laminae is ongoing (Meissirel et al., 1997). In situ hybridization to both NEFL and IN $\alpha$ displayed dense signal overlying nuclei of the dorsal thalamus, including the dLGN (Fig. 10). Expression levels of NEFM were lower, but positive signal was also observed throughout the dLGN (data not shown). As was the case in adult brain, expression of TCF7L2 was primarily restricted to nuclei of the dorsal thalamus (Fig. 10D). Strong hybridization signal to TCF7L2 mRNA was observed over most dorsal thalamic nuclei, but no signal was detected over nuclei of the epithalamus or other brain regions including neocortex or ganglionic eminence (Fig. 10, compare $B, D$ ). In contrast to expression of TCF7L2 in parvocellular laminae of adult dLGN or to the robust expression of NEFL and IN $\alpha$ mRNA in E55 dLGN (Fig. 10), only low levels of TCF7L2 hybridization signal were observed in dLGN at E55 (Fig. 10D).

\section{Discussion}

In this study, we have identified 10 new cellular markers for magnocellular neurons and one new marker for parvocellular and koniocellular neurons. The genes whose expression these markers represent are associated with neuronal development and cell signaling and may play important functional roles in the establishment and maintenance of the remarkable morphological, physiological, and connectional specificity exhibited by the cellular layers of the dLGN. The observation that a subset of these markers is differentially expressed during a period of embryogenesis when magnocellular and parvocellular pathways are formed lends support to this notion. Before discussing the significance of these findings, some technical issues will be considered.

\section{Technical considerations}

The cellular expression patterns revealed by in situ hybridization agreed well with the differential pattern identified by microarray analysis. However, expression of three genes, CAV1, SFRP2, and TCF7L2, was opposite that of the microarray analysis (compare Figs. 3, 4). Two factors may contribute to this observation. First, RNA amplification could produce results opposite those seen with nonamplified conventional array hybridization strategies and/or RT-PCR (Puskás et al., 2002; Li et al., 2003; van Haaften et al., 2006). Although the mechanism(s) are unknown, this effect is greater on lower abundance RNAs such as CAV1 and SFRP2 (Fig. 5). Second, microdissection could introduce a sampling bias. This is especially true for primate dLGN, where variable numbers koniocellular neurons interleafed between magnocellular and parvocellular layers could account for differences between microarray and RT-PCR observations.

We identified 11 novel dLGN laminar markers, but no commonly used dLGN markers. Both Cat-301 (Hendry et al., 1984) and SMI-32 (Gutierrez et al., 1995; Chaudhuri et al., 1996) are monoclonal antibodies that recognize structural components of proteins and do not necessarily reflect the abundance of corresponding mRNA. Also, these markers are not exclusive to magnocellular laminae which could further limit their detection using the methods used herein (Hendry et al., 1984). Despite 
A

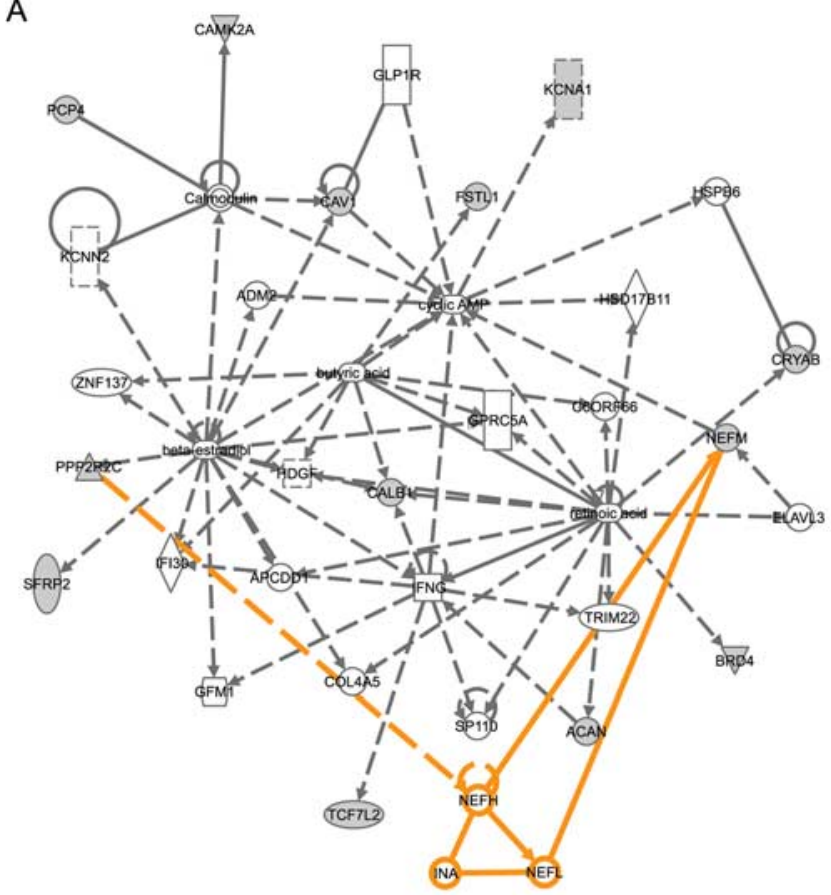

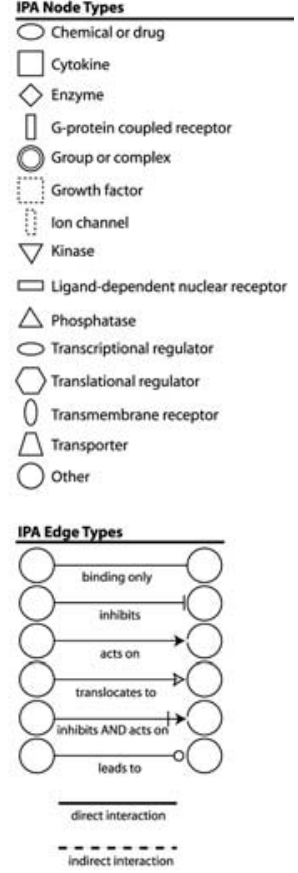

B Ingenuity Pathways Analysis Newtorks

\begin{tabular}{|c|c|c|c|c|}
\hline ID & Molecules in Network & Score & $\begin{array}{c}\text { Focus } \\
\text { Molecules }\end{array}$ & Top Functions \\
\hline 1 & $\begin{array}{l}\text { ACAN, ADM2, APCDD1, beta-estradiol, BRD4, butyric acid, } \\
\text { C6ORF66, CALB1, Calmodulin, CAMK2A, CAV1, COL4A5, } \\
\text { CRYAB, Cyclic AMP, ELAVL3, FSTL1, GFM1, GLP1R, } \\
\text { GPRC5A, HDGF, HSD17B11, HSPB6, IFI30, IFNG, KCNA1, } \\
\text { KCNN2, NEFM, PCP4, PPP2R2C, retinoic acid, SFRP2, } \\
\text { SP110, TCF7L2, TRIM22, ZNF137 }\end{array}$ & 36 & 13 & $\begin{array}{l}\text { Cancer, Cellular function } \\
\text { and maintainence, Cell } \\
\text { death }\end{array}$ \\
\hline 2 & CEBPA, CHRM4, EEF1A2, Protein-synthesizing GTPase & 3 & 1 & $\begin{array}{l}\text { Cell Cycle, Connective } \\
\text { Tissue Development and } \\
\text { Function, Molecular } \\
\text { Transport }\end{array}$ \\
\hline
\end{tabular}

Figure 8. IPA was performed using a gene set combined of the novel cell-specific dLGN layer markers identified and those previously reported. $\boldsymbol{A}$, Thirteen of 15 molecules queried were mapped to a single IPA network. Manual expansion of the network (nodes and edges in orange) identified a connection between the phosphatase subunit, PPP2R2C, and the neurofilament protein NEFM via the neurofilament molecules NEFH, NEFL, and IN $\alpha$. Nodes and edge symbols are explained in legends at right. Open symbols, Network molecules identified by IPA. Filled symbols, Confirmed dLGN layer-specific markers (focus molecules). B, Two networks of proteins associated through direct and indirect interactions at a level greater than chance were identified and scored based on the number of input genes (focus molecules) linked with the network. The top functions and/or diseases significantly overrepresented by molecules in these networks are listed.

previous validation of monkey RNA on human Affymetrix microarrays (Murray et al., 2007; Lachance and Chaudhuri, 2007) other markers such as OCC1 (Tochitani et al., 2001), or NEFM (Prasad et al., 2002), may not cross-hybridize well enough for detection.

\section{Comparison with previous findings}

Three previous studies addressed the issue of molecular specificity of dLGN layers (Prasad et al., 2000; Kawasaki et al., 2004; Lachance and Chaudhuri, 2007), and we also provided preliminary data relevant to the present study (Murray et al., 2007). In a previous genome-wide screen for thalamusspecific genes, we identified osteopontin (SPP1) and osteonectin $(S P A R C)$ as genes expressed only in dLGN (SPP1) or within subsets of dLGN neurons (SPARC). Prasad et al. (2000) found a greater number of magnocellular enriched genes (300) compared with parvocellular (107) in the dLGN of vervet (Chlorocebus pygerythrus) monkey; however, no cellular confirmation was obtained. None of the genes they listed was found here (compare their Table 4 with our Fig. 3), and this is likely attributable to many of their top candidates corresponding to expressed sequence tags that had not yet been mapped to specific genes. Kawasaki et al. (2004) describe PCP4 as a magnoenriched gene in monkey dLGN, although our own observations suggest laminar differences are likely below the cutoff criteria set in the present study. A recent study by Lachance and Chaudhuri (2007) identified neuron and gliaspecific genes in macaque dLGN, but none showed magnocellular or parvocellular layer enrichment.

\section{Wnt signaling and layer specific patterning in monkey dLGN (PPP2R2C, SFRP2, TCF7L2)}

PPP2R2C, SFRP2, and TCF7L2 are members of the developmentally important, canonical $\mathrm{Wnt} / \beta$-catenin signaling pathway. The protein product of $P P P 2 R 2 C$ is part of the phosphatase 2 regulatory subunit $B$ family of serine/ threonine phosphatases that has been shown to modulate $\beta$-catenin activity (Seeling et al., 1999; Li et al., 2001; Baek and Seeling, 2007). TCF7L2 is a member of the Tcf/Lef (T-cell factor/lymphoid enhancer factor) subfamily of transcription factors (Korinek et al., 1997) (for review, see Ciani and Salinas, 2005). SFRP2 is part of a family of proteins that contains domains homologous to the Wnt binding site on frizzled receptor (Rattner et al., 1997). Collectively, these proteins can modulate Wnt signaling at a variety of levels.

IPA analysis indicates that identification of the genes described above is not likely to be attributable to chance and implicates the Wnt $/ \beta$-catenin pathway in the formation of functionally distinct dLGN layers. Canonical signaling through the $\mathrm{Wnt} / \beta$-catenin pathway has primarily been associated with progenitor zones that delineate neural boundaries in early embryogenesis (Puelles and Rubenstein, 2003; Lim and Golden, 2007). A number of studies have shown that early expression of Wnt genes in the anlage of the dorsal thalamus and in the zona limitans intrathalamica, is necessary for proper differentiation of thalamic nuclei (Garda et al., 2002; Braun et al., 2003; Zhou et al., 2004). Wnt signaling can determine neuronal connectivity directly through axon guidance mechanisms (Ille and Sommer, 2005; Endo and Rubin, 2007). In particular, loss of the Wnt receptor frizzled-3 leads to severe defects of mouse thalamocortical and corticothalamic pathways, implying that thalamic connectivity is dependent on Wnt signaling (Wang et al., 2002). Our results extend these studies, showing that many of the genes identified in the adult dLGN are also expressed as early as E55 in the fetal brain, and implicate Wnt signaling in the maintenance of 

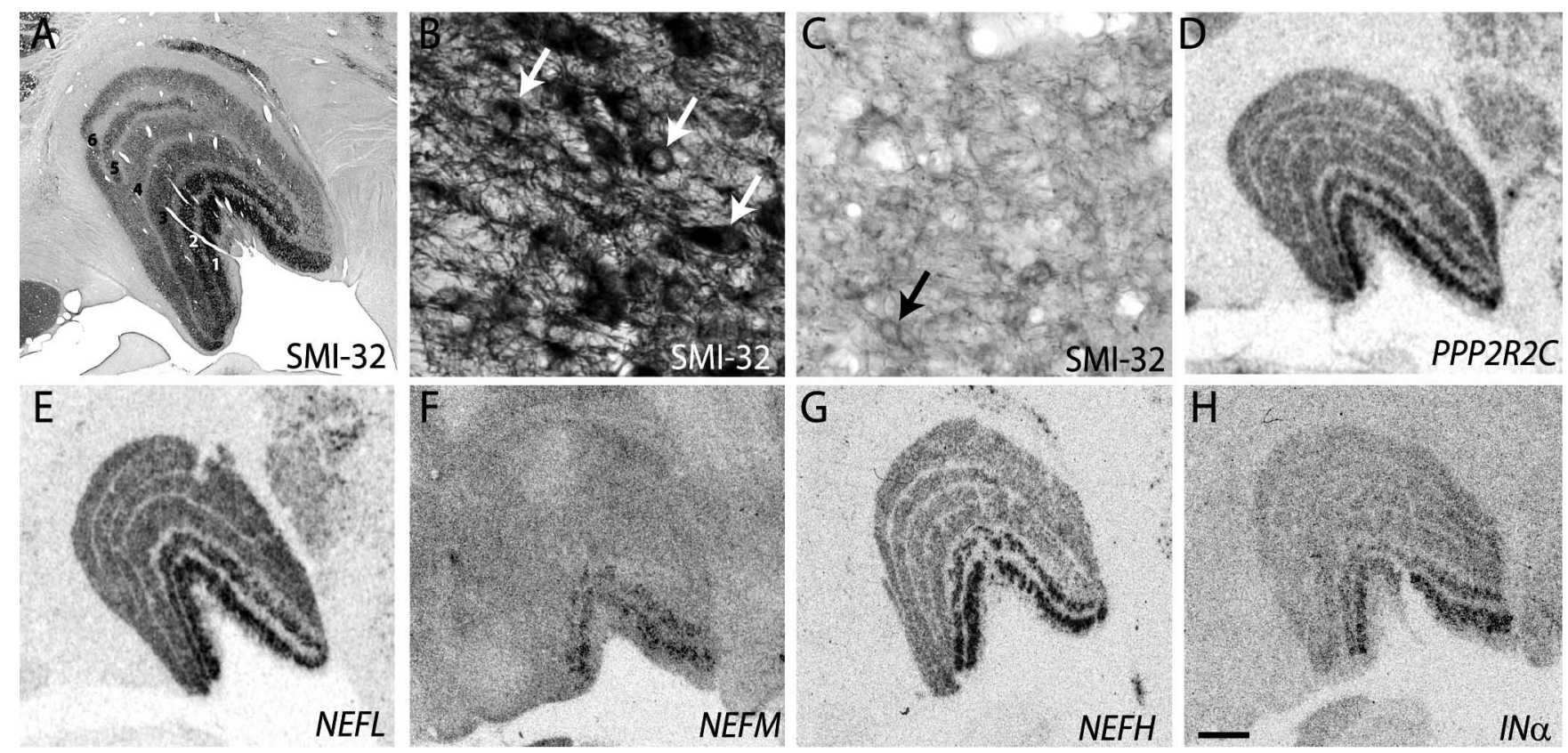

Figure 9. Phosphatase activity and neurofilament expression is greater in magnocellular layers of monkey dLGN. $A$, Immunohistochemical staining of a coronal dLGN section with SMI-32 monoclonal antibody showing increased staining of the magnocellular layers $(1,2)$ of the dLGN compared with parvocellular layers $(3-6)$. $\boldsymbol{B}, \boldsymbol{C}$, Higher power images of SMI-32 immunostaining shows denser reaction product over layer $1(\boldsymbol{B})$ compared with layer $6(\boldsymbol{C})$ and illustrate positive immunoreactivity within cell bodies (arrows). $\boldsymbol{D}-\boldsymbol{H}$, Autoradiographic images of coronal dLGN sections processed for in situ hybridization showing increased hybridization of riboprobes specific to PPP2R2C (D),NEFL (E),NEFM (F),NEFH (G), and IN $\alpha(\boldsymbol{H})$ mRNA in magnocellular layers of the dLGN. Scale bar: (in $\boldsymbol{H}) \boldsymbol{A}-\boldsymbol{H}, 1 \mathrm{~mm}$.

functional segregation of visual pathways in monkey dLGN into adulthood.

\section{Neurofilament signaling and layer-specific patterning in monkey dLGN (NEFL, PPP2R2C, SMI-32, NEFM, NEFH, IN $\alpha$ )}

We describe for the first time magnocellular-specific expression of NEFL, NEFH, IN $\alpha$, and PPP2R2C in monkey dLGN. Coupled with the previously reported expression of NEFM in magnocellular dLGN layers (Prasad et al., 2002), this suggests a pattern of neurofilament signaling specific to magnocellular layers of the monkey dLGN.

Specific labeling of nonphosphorylated neurofilament (NEFH and NEFM) proteins by the monoclonal antibody SMI-32 in neurons within magnocellular layers of the dLGN (Fig. 9) suggests a pattern of posttranslational modification specific to these layers. The overexpression of $P P P 2 R 2 C$, which encodes the B1 g subunit of protein phosphatase 2A (PP2A) (Hu et al., 2000), in magnocellular layers reported here supports this idea and provides a mechanism by which SMI-32 specifies magnocellular dLGN neurons. It is unknown whether other subunits of the PP2A holoenzyme complex are specifically localized to magnocellular layers. However, enrichment of the B1 g subunit, responsible for subcellular movement of the holoenzyme, could be related to neurofilament targeting and subsequent development of neurites (Lechward et al., 2001). Indeed, overexpression of PPP2R2C in a heterologous cell line enhances growth factorinduced neurite outgrowth and increases expression of NEFH (Strack, 2002). Similar links between the other well known marker Cat-301 and lamina-enriched genes are not obvious. However, chondroitin sulfate proteoglycans, the target moiety that Cat-301 recognizes, are well documented regulators of neurite outgrowth (Margolis and Margolis, 1997).

\section{Laminar markers in fetal monkey}

A subset of adult monkey dLGN lamina-specific markers was observed to be expressed in the embryonic monkey dLGN at E55, a critical period of development when retinal axons are terminating selectively in magnocellular and parvocellular specific zones (Meissirel et al., 1997). The subset of markers investigated in the adult dLGN (NEFL, IN $\alpha, N E F M$, and TCF7L2) is representative of the functional pathways associated with the adult markers and was significantly enriched in magnocellular or parvocellular lamina in adult dLGN. Rather than obvious regional differences, magnocellular enriched markers (NEFL, IN $\alpha, N E F M)$ at E55 were found to be expressed throughout the fetal dLGN. At this age, TCF7L2, which in the adult labeled prominently the parvocellular layers, was barely above background levels. Classic work by Rakic (1977) on fetal monkey showed a clear gradient of neurogenesis, with neurons in the presumed magnocellular layers born before those in the parvocellular layers during the period from E36 to E45. Thus, the pattern of expression observed in the E55 monkey reflects maturational differences between magnocellular and parvocellular cells. Importantly, our data reveal one subset of markers that appear to identify magnocellular cells of the dLGN at a time shortly after their generation.

\section{Implications for development}

The present observations implicate $\mathrm{Wnt} / \beta$-catenin signaling and neurofilament regulation in the development of lamina specificity in the monkey dLGN. The morphological development of the retinogeniculate pathway in the fetal macaque has been well documented and certain key phases have been identified. These include an early fetal period during which magnocellular and parvocellular pathways are initially formed (Meissirel et al., 1997), a subsequent establishment of eye-specific terminations (Huberman et al., 2005), as well as a period during which retinogenicu- 

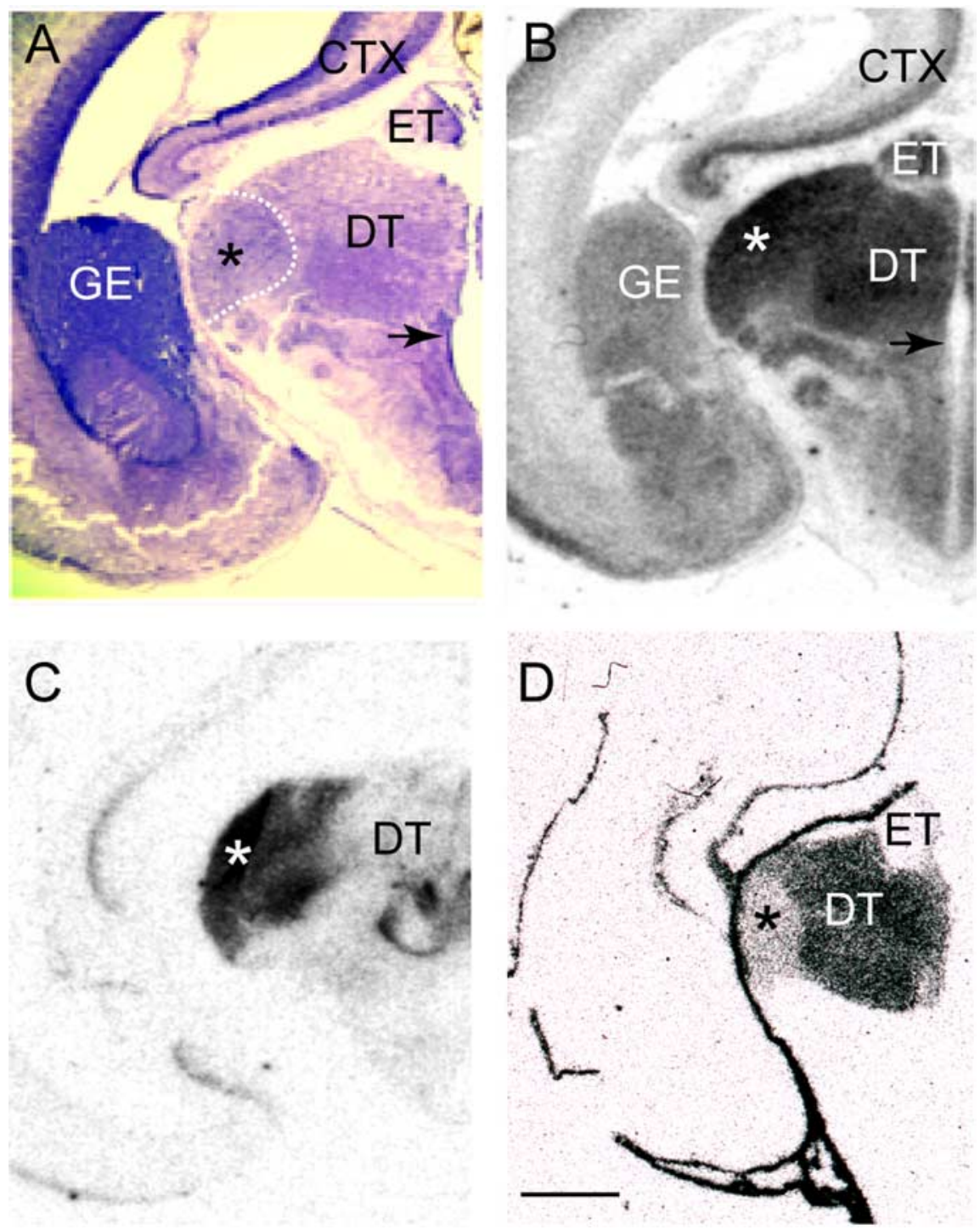

Figure 10. Markers of dLGN laminae in adult brain are expressed in E55 thalamus. $A$, Coronal Nissl-stained section through an E55 monkey thalamus illustrating cytoarchitectural differentiation of thalamic nuclei. The location of the dLGN (*) in relation to the anlagen of dorsal thalamus (DT) and epithalamus (ET) is indicated by the dashed bounding box. M, P, or K laminae cannot be reliably identified at this age (Huberman et al., 2005). An arrow indicates the location of the third ventricle. $\boldsymbol{B}-\boldsymbol{D}$, Autoradiographic images of coronal sections adjacent to that in $\boldsymbol{A}$ processed for in situ hybridization with riboprobes specific to the genes NEFL (B), IN $\alpha(\mathbf{C}$, and TCF7L2 (D). NEFL and IN $\alpha$ are both heavily expressed in the developing dLGN, whereas TCF7L2 displays relatively low levels of expression. Scale bar: (in D) $\boldsymbol{A}-\boldsymbol{D}, 1 \mathrm{~mm}$. Abbreviations: CTX, Neocortex; DT, dorsal thalamus; ET, epithalamus; GE, ganglionic eminence.

late axon arbors are elaborated (Snider et al., 1999). The dynamics of spontaneous retinal activity in the fetal monkey have also been documented (Warland et al., 2006) and may play a role in the activity-dependent refinement of retinogeniculate projections (Chalupa, 2007). The linkage of the gene expression profiles identified in the present study with the onset of correlated retinal discharges will clearly be an important issue in future work. The present study lays the foundation for assessing how expression of layer-specific markers correlates with key developmental events and how perturbations of these molecules will impact the formation of layer-specific retinogeniculate projections.

\section{References}

Baek S, Seeling JM (2007) Identification of a novel conserved mixedisoform B56 regulatory subunit and spatiotemporal regulation of protein phosphatase 2A during Xenopus laevis development. BMC Dev Biol 7:139.
Barker N, Huls G, Korinek V, Clevers H (1999) Restricted high level expression of Tcf-4 protein in intestinal and mammary gland epithelium. Am J Pathol 154:29-35.

Benson DL, Isackson PJ, Hendry SH, Jones EG (1991) Differential gene expression for glutamic acid decarboxylase and type II calciumcalmodulin-dependent protein kinase in basal ganglia, thalamus, and hypothalamus of the monkey. J Neurosci 11:1540-1564.

Braun MM, Etheridge A, Bernard A, Robertson CP, Roelink H (2003) Wnt signaling is required at distinct stages of development for the induction of the posterior forebrain. Development 130:5579-5587.

Callaway EM (2005) Structure and function of parallel pathways in the primate early visual system. J Physiol 566:13-19.

Chalupa LM (2007) A reassessment of the role of activity in the formation of eye-specific retinogeniculate projections. Brain Res Rev 55:228-236.

Chaudhuri A, Zangenehpour S, Matsubara JA, Cynader MS (1996) Differential expression of neurofilament protein in the visual system of the vervet monkey. Brain Res 709:17-26.

Ciani L, Salinas PC (2005) WNTs in the vertebrate nervous system: from patterning to neuronal connectivity. Nat Rev Neurosci 6:351-362.

Endo Y, Rubin JS (2007) Wnt signaling and neurite outgrowth: insights and questions. Cancer Sci 98:1311-1317.

Erondu NE, Kennedy MB (1985) Regional distribution of type $\mathrm{II} \mathrm{Ca}{ }^{2+} /$ calmodulin-dependent protein kinase in rat brain. $J$ Neurosci 5:3270-3277.

Garda AL, Puelles L, Rubenstein JL, Medina L (2002) Expression patterns of Wnt8b and Wnt7b in the chicken embryonic brain suggest a correlation with forebrain patterning centers and morphogenesis. Neuroscience 113:689-698.

Gutierrez C, Yaun A, Cusick CG (1995) Neurochemical subdivisions of the inferior pulvinar in macaque monkeys. J Comp Neurol 363:545-562.

Hendry SH, Reid RC (2000) The koniocellular pathway in primate vision. Annu Rev Neurosci 23:127-153.

Hendry SH, Hockfield S, Jones EG, McKay R (1984) Monoclonal antibody that identifies subsets of neurones in the central visual system of monkey and cat. Nature 307:267-269.

Hu P, Yu L, Zhang M, Zheng L, Zhao Y, Fu Q, Zhao S (2000) Molecular cloning and mapping of the brain-abundant B1gamma subunit of protein phosphatase 2A, PPP2R2C, to human chromosome 4p16. Genomics 67:83-86.

Huberman AD, Dehay C, Berland M, Chalupa LM, Kennedy H (2005) Early and rapid targeting of eye-specific axonal projections to the dorsal lateral geniculate nucleus in the fetal macaque. J Neurosci 25:4014-4023.

Ille F, Sommer L (2005) Wnt signaling: multiple functions in neural development. Cell Mol Life Sci 62:1100-1108.

Jones EG (2007) The thalamus, Ed 2. Cambridge, UK: Cambridge UP.

Kaplan E (2004) The M, P and K pathways of the primate visual system. In: The visual neurosciences (Chalupa LM, Werner JS, eds), pp 481-493. Cambridge, MA: MIT.

Kawasaki H, Crowley JC, Livesey FJ, Katz LC (2004) Molecular organization of the ferret visual thalamus. J Neurosci 24:9962-9970.

Korinek V, Barker N, Morin PJ, van Wichen D, de Weger R, Kinzler KW, Vogelstein B, Clevers H (1997) Constitutive transcriptional activation 
by a beta-catenin- $\mathrm{Tcf}$ complex in $\mathrm{APC}^{-1-}$ colon carcinoma. Science 275:1784-1787.

Lachance PE, Chaudhuri A (2007) Gene profiling of pooled single neuronal cell bodies from laser capture microdissected vervet monkey lateral geniculate nucleus hybridized to the Rhesus Macaque Genome Array. Brain Res 1185:33-44.

Lechward K, Awotunde OS, Swiatek W, Muszyńska G (2001) Protein phosphatase 2A: variety of forms and diversity of functions. Acta Biochim Pol 48:921-933.

Lee MK, Cleveland DW (1996) Neuronal intermediate filaments. Annu Rev Neurosci 19:187-217.

Li J, Adams L, Schwartz SM, Bumgarner RE (2003) RNA amplification, fidelity and reproducibility of expression profiling. C R Biol 326:1021-1030.

Li X, Yost HJ, Virshup DM, Seeling JM (2001) Protein phosphatase 2A and its B56 regulatory subunit inhibit Wnt signaling in Xenopus. EMBO J 20:4122-4131.

Lim Y, Golden JA (2007) Patterning the developing diencephalon. Brain Res Rev 53:17-26.

Margolis RU, Margolis RK (1997) Chondroitin sulfate proteoglycans as mediators of axon growth and pathfinding. Cell Tissue Res 290:343-348.

McKay RD, Hockfield SJ (1982) Monoclonal antibodies distinguish antigenically discrete neuronal types in the vertebrate central nervous system. Proc Natl Acad Sci U S A 79:6747-6751.

Meissirel C, Wikler KC, Chalupa LM, Rakic P (1997) Early divergence of magnocellular and parvocellular functional subsystems in the embryonic primate visual system. Proc Natl Acad Sci U S A 94:5900-5905.

Murray KD, Choudary PV, Jones EG (2007) Nucleus- and cell-specific gene expression in monkey thalamus. Proc Natl Acad Sci USA 104:1989-1994.

Prasad SS, Kojic LZ, Lee SS, Chaudhuri A, Hetherington P, Cynader MS (2000) Identification of differentially expressed genes in the visual structures of brain using high-density cDNA grids. Brain Res Mol Brain Res $82: 11-24$.

Prasad SS, Schnerch A, Lam DY, To E, Jim J, Kaufman PL, Matsubara JA (2002) Immunohistochemical investigations of neurofilament $\mathrm{M}^{\prime}$ and alphabeta-crystallin in the magnocellular layers of the primate lateral geniculate nucleus. Brain Res Mol Brain Res 109:216-220.

Puelles L, Rubenstein JL (2003) Forebrain gene expression domains and the evolving prosomeric model. Trends Neurosci 26:469-476.

Puskás LG, Zvara A, Hackler L Jr, Van Hummelen P (2002) RNA amplification results in reproducible microarray data with slight ratio bias. Biotechniques 32:1330-1334, 1336, 1338, 1340.

Rakic P (1977) Genesis of the dorsal lateral geniculate nucleus in the rhesus monkey: site and time of origin, kinetics of proliferation, routes of migration and pattern of distribution of neurons. J Comp Neurol 176:23-52.

Rattner A, Hsieh JC, Smallwood PM, Gilbert DJ, Copeland NG, Jenkins NA, Nathans J (1997) A family of secreted proteins contains homology to the cysteine-rich ligand-binding domain of frizzled receptors. Proc Natl Acad Sci U S A 94:2859-2863.

Seeling JM, Miller JR, Gil R, Moon RT, White R, Virshup DM (1999) Regulation of beta-catenin signaling by the B56 subunit of protein phosphatase 2A. Science 283:2089-2091.

Sincich LC, Horton JC (2005) The circuitry of V1 and V2: integration of color, form, and motion. Annu Rev Neurosci 28:303-326.

Sincich LC, Park KF, Wohlgemuth MJ, Horton JC (2004) Bypassing V1: a direct geniculate input to area MT. Nat Neurosci 7:1123-1128.

Snider CJ, Dehay C, Berland M, Kennedy H, Chalupa LM (1999) Prenatal development of retinogeniculate axons in the macaque monkey during segregation of binocular inputs. J Neurosci 19:220-228.

Sternberger LA, Sternberger NH (1983) Monoclonal antibodies distinguish phosphorylated and nonphosphorylated forms of neurofilaments in situ. Proc Natl Acad Sci U S A 80:6126-6130.

Sternberger LA, Harwell LW, Sternberger NH (1982) Neurotypy: regional individuality in rat brain detected by immunocytochemistry with monoclonal antibodies. Proc Natl Acad Sci U S A 79:1326-1330.

Strack S (2002) Overexpression of the protein phosphatase 2A regulatory subunit Bgamma promotes neuronal differentiation by activating the MAP kinase (MAPK) cascade. J Biol Chem 277:41525-41532.

Tochitani S, Liang F, Watakabe A, Hashikawa T, Yamamori T (2001) The occl gene is preferentially expressed in the primary visual cortex in an activity-dependent manner: a pattern of gene expression related to the cytoarchitectonic area in adult macaque neocortex. Eur J Neurosci 13:297-307.

Van Gelder RN, von Zastrow ME, Yool A, Dement WC, Barchas JD, Eberwine JH (1990) Amplified RNA synthesized from limited quantities of heterogeneous cDNA. Proc Natl Acad Sci U S A 87:1663-1667.

van Haaften RI, Schroen B, Janssen BJ, van Erk A, Debets JJ, Smeets HJ, Smits JF, van den Wijngaard A, Pinto YM, Evelo CT (2006) Biologically relevant effects of mRNA amplification on gene expression profiles. BMC Bioinformatics 7:200.

Wang Y, Thekdi N, Smallwood PM, Macke JP, Nathans J (2002) Frizzled-3 is required for the development of major fiber tracts in the rostral CNS. J Neurosci 22:8563-8573.

Warland DK, Huberman AD, Chalupa LM (2006) Dynamics of spontaneous activity in the fetal macaque retina during development of retinogeniculate pathways. J Neurosci 26:5190-5197.

Yan YH, Winarto A, Mansjoer I, Hendrickson A (1996) Parvalbumin, calbindin, and calretinin mark distinct pathways during development of monkey dorsal lateral geniculate nucleus. J Neurobiol 31:189-209.

Zaremba S, Guimaraes A, Kalb RG, Hockfield S (1989) Characterization of an activity-dependent, neuronal surface proteoglycan identified with monoclonal antibody Cat-301. Neuron 2:1207-1219.

Zhou CJ, Pinson KI, Pleasure SJ (2004) Severe defects in dorsal thalamic development in low-density lipoprotein receptor-related protein-6 mutants. J Neurosci 24:7632-7639. 